7. 回盲毁矮は虫垂動脈の第一分枝が流入し回腸末端 の腸間膜反対側に及び，血管に並行して神経楾䧽も認好 られるから小腸大腸間の運動伝達とか, 回盲弁口の開閉 等に何等かの生理的意義ある如くでもあるので，㩔䇒切 除を強くは推賞しないが切断又は切除によつて回盲部を 生理的運動状態にするととで執拗な苦悩が噸挫的に消失 快瘾した67症列を経験した。

8. 以上 8 年間の切除例その他演題関係1304症例より 受けた往復ハガキの解答 323 例は全例永続治湶の現海に ある。

9 . 以上恩師頼尾自信教授の生理的手術の主張汃盲 腸固定術の如きは不要との考元のもとに繾縮又は固定術 等を手術的に解離し好結果を見た症例も少なくないが， 本論を脱するので割愛する。

10. 虫垂切除街の一般化の結果慢性虫垂炎之同一な後 遣症を残し，苦悩の執拗深刻なため蟨々胃切除も行なわ れている現実は厳しく反省されなくてはならない。

\section{II-99 局所性腸炎自験例の検討}

第原病院 古川 明, 乙部 正治
長浜 遠

局所性腸炎には未解決の問題が多く，昨年の本会にお いても，急性型につき論ぜられた。わたくしどもは約 10 年間に，本症の50例を経耠したので，少しく検討を加え た。年度・月別頻度をみると，本症は散発するようにみ えるが，まれに頻発する傾向を認めた。病型は急性 36 , 覀急性 10 , 慢性 4 である。性は男がやや多く, 年令は 6 〜51才で，20代に最も多かつた。全例手術によつて診断 を確かめたが，術前の診断はむずかしく，虫垂炎が43で 大部分を占めている。前駆症状として，感冒性症状の多 いととは，前記のまれにみる本症の頻発とともに注目す べきことで，多数例の集計調查によれば，本症の誘因・ 原因にたいして何かのヒントが与えられるように思われ る。大多数例の治療は虫垂切除であるが，腸切除 8 例を 施した。篗息部位は回盲弁より口側 $100 \mathrm{~cm}$ までのものが 多く，270cmに達したもの, 反対に盲腸におよんだものが ありまた skip-lesions を示したものが2例ある。切 除例は急性 3 ,亜急性 1 ，慢性 4 で，予後は良好である。

急性型は腸壁の発赤・肥厚・浮腫・腸間膜リンパ節腫 脹などを認める。組織的には粘膜固有層より獎膜にかけ ての白血球とくに好酸球浸潤・漿膜下層わよび粘膜下㞒 の充血・浮腫・線維素析出などによる肥厚がみられ, 䐬 濝や壊死を認めない。急性型は保存的療法で治瘾するこ とが多いため，切除の可否が問題になる。また本症のあ るものは強力な化学療法を要するてとがあるので, 手術
創の小さいため本正を見逃してはならない。 skip-le sions を呈した慢性型 2 例はイレウス・穿孔性腹膜炎を 併発したるのである。回腸・杗腸・腸間膜リンパ節で埂 湢を形成した慢性例は線維增殖性虫垂炎様であるが，虫


的には，粘膜下首を中心に獎膜方向にも波及した肉芽婳 樣炎症で巨，細胞がみられ，リンパ球を主とした細胞機 構をもつている。

\section{II-100 慢性クローン氏病の 3 手術治験例 済生会宇都宮病院

梅園 明, ○佐藤
川褧二
川村 豊文, 熊谷 義也
石飛 幸三

最近の 2 年間に経験せる 3 例の慢性クローン氏病につ いて報告する。

I 60 才，女，2 週間前より胃部不快感があり，超盲 部可動性腫㾴をふれ，開腹した所，虫垂根部から盲腸末端 に硬い䭪煌形成があるため, 廻盲部切除術を行つた。標 本の組織学的所見は好中球，好酸球浸潤をともなつた線 維増殖によるものであり，クローン氏病の一型と考えら れる慢性線維形成虫垂炎であつた。

I 20 才, 男, 3 年前より肛門部出血があり庠核, 肛 門ポりープ等の診断にて治療をうけていたが軽快せず, るいそう, 䝯血, 発熱, 膿血性下㢉, 肛門部びらんをと まなつて来院す。輸血，抗性物質，副腎皮質ホルモン投 与を行い，人工肛門造設し，全身状態の改善をまつて手 術をした。上行結腸以外の全大腸に壁肥厚, 発赤, 1 部 に周囲との癁着があり，漬瘍性大腸炎の診断のもとに全 結腸直腸切除術を行つた。標本の組織学的所見は広笓な 䟺瘍形成と粘膜下の著明なうつ血と浮腫, 強い細胞浸潤 リンパ球浸潤と巨細胞をともなつた小肉芽腫が全腸管に 見られ，下部腸管ほど変化は古く著明であり，直腸に初 発したと思われるクローン氏病と判明した。

II 67才, 男, 2 週間前より胃部不快感と交代性下蔽 があり，趈盲部に可動性の腫箅をるれ，開腹しますと廻 腸終末から盲腸にかけて発赤せる約 $8 \mathrm{~cm}$ の腸管壁肥厚が あるため迴盲部切除を行つた。標本の組織学的所見は粘 膜下の強い浮腫が主でリンパ管の拡張，リンパ濾胞棣結 節が多数あり，巨細胞をもつた小肉芽腫も見出され，定 型的なクローン氏病と䛦断された。

我国におけるクローン氏病の報告は石倉による370 例 の統計が最大であり，その他にも多くの報告があるが慢 性型は比較的小数である様に思われる。今回の 3 症例は いゔれも慢性型であり，直腸に初発したと思われる症例 
Iは海外でも少なく潰㻛性大腸炎と同一視するもの，そ の合併を主張するものもあるが，一方，臨床的組織学的 にそのかん別をくわしく報告しているものもある。治療

第 8

座長 山 根斎 博士

\section{IIー101 いわゆる回盲症に対する，回盲部形成術の 効果について}

京都松井病院 木村 昭, 金 在 河

国立舞鹤病院外科 大同礼次郎

回盲部愁訴を来す矤息は，炎症，原瘍を除いて，瘜着 症, 移動性盲腸症, 弁狭窄, 慢性便泌等があげられる。 之等疾患の表わす愁訴は，主として，異常臌满，，自発 痛, 索引痛, 圧痛等であり，われわれは，之等を総称し で回盲症"と呼んている。

之等回盲应に対して，注腸及び徍口的造影を行い，そ の大多数に移動性盲腸症及び常習性便议症特に上行結腸 型便泌㱏を認めたので，その56例に回盲部形成術を行い 極めて良好な成續を得たのでててに報告する。

従来, 移動性盲腸症及び慢性便泌定に対する術式は, 固定, 縫縮, 神経切除, 腸切除の籁囲に限られて居り, 一応の効果を収めては居るが，反面，後遺症や侵熋の大 きに過ぎるきらいがある。

われわれの行っている術式は，1958年，村上氏力溌表 し，その後大同等が追試した如く，Finney 氏幽門成 形術に似た，弁形成術である。即ち終末回腸部の Plica ileocecalis caudalis を切除し, その切除線沿つて, 弁の前面を横断し，虫垂根部に向う $5 \sim 6 \mathrm{~cm}$ の 切開を 行つて, 下弁を結禁後, 横縫合を行い, 回, 盲腸を側々 吻合する様にする。之によつて, 弁口部の開大と, 盲端 部下垂の减弱を計るわけであり，結果的には，Kirsch ner 等の回盲切除術と効果を同しくし，しかるその侵警 を著しく少くすることが出来る。

われわれは，過去 2 ケ年半に移動性盲腸症 42 例，上行 結㿢型便泌店 10 例, その他 4 例, 計56例に上記手術を行 い，1ケ月後より2 2 ケ年半迄のそれぞれの遠隔成續を得 た即ち，疼痛に対し94\%，便必住対し54\%，回盲症全体 として77\%の効果を治めて居り，後遺症は 1 例も見られ なかつた。

移動性盲渴症は，内臓下垂症の一分症として晹 Dysk inesie の部分的発現と考元られる為，慢性便议症と共 に，腸筋電図等を含む機能的検查を併用しつつ研究して 行きたいと思う。

追 加
成績を見ると再発が多いため広範囲切除がー般化しつつ ある。

群

岐皁市村上病院 村上 治胡

回盲弁形成術後貽症がなかたという報告に意をつよ くした。オーストラリアの Hugh 氏はその著書でこの 弁に手術か加光ら机ると必ずあとが悪いと書いているの で，私も同様な手術をするのであるが，ての点を常に心 配しているのである。弁が内容の逆流を阻止し，しかも 回盲痛のあるものを私は本手術の適応と考えているので あるが，その診断には経肛門的にバリウムを注入して弁 をてれが通過するかどうかではとれは診断するととは出 来ず，経口的にバリウムをのんでて机が盲腸部に大量に 永く停膟するかどうかで決めるべきものである。

\section{II－102 所請慢性虫垂炎の治療 一特に莧物㾳法の効果について一 市立江別棇合病院外科 \\ ○池永 和親，西部 哲雄 金子 輝夫}

我々は昭和36年 4 月より本年 3 月までの間に急性虫垂 炎, 慢性虫垂炎, 或は虫垂切除術後障害として当科を訪 れた 294例について，その治療成績の効果をアンケート により検討した。

先ず所謂慢性虫垂炎は，男性31例付対し女性109例。約 1 対 3 之压倒的纪性に多人, 又20才代，30才代に多く 見られ，又虫垂切除後なお回盲部疼痛を訴光るものが， 慢性虫垂炎之診断されたもの亿意外に多いのに整いてお り，再手術をうけた者も10例あつた。

我々は腹部所見，血萑所見が救急手術を必要としない てれ等患者に対しては直ちに観血的治療は加えず, 胃液 検查の後, 周部, 回盲部, 及び $\mathrm{S}$ 状結腸部のレ線検查を施 行し，内藏下垂又は移動性盲腸の認められる者対して は, 腹痛, 便通の状㦔々共侸痛, 矓晕, 動悸等所定の 問診事項をただし，交感神経遮断剂，副交感神释六進剂 及少数に厘液腺ホルモン等の投与を行い，胃下垂高度の 者に対しては胃下垂バンド着用を行つた。とれ等の効果 も見るべきものがあつたが，尚てれにても愁訴軽減せず その治療に当惑していたが，乙れ等患者か瀛瘦強く，所 謂無力性体質を有する者の多い事から，蛋白同化ホルモ ンによる肥㭌療法に着目し，13例に19N.A.P.P-週25 $\mathrm{mg} \sim 50 \mathrm{mg}$ を筋注したとてろ、約 4 週目より体重增加と 共愁訴轻娍し，途中中止した1例を除き，12例中10例 
に著効を見た。又最近は内服薬H.M.Dを 5 例に投与し て見たが，てれも全例好い結果を得ている。

以上の経験より現在, 常習便泌, 移動盲腸症に対し, 理々の観血的治療が行なわれているが，その術式の適応 には充分の配虑をはらわれると共に，薬物療物にても効 果のあげ得る事を強調したい。

\section{II－103 日本住吸血虫畉による虫垂炎について 順天堂大第 2 外科 \\ 山瀬敏, 高垣 衛 \\ 古沢 公晴, 富田 滝三}

日本住血吸虫卵の虫垂壁介在による虫垂炎に就いては 多数の報告例があるが，我々は山梨県下で経験した虫垂 炎 105例中15例に，虫垂壁に虫卵の介在を認めたので報 告する。

臨床应状としては一般虫垂炎に比較して特街的るもの はなく，比較的新鮮卵の場合には好酸球の增多があり， 組織学的にも同種細胞の浸潤を認める。尚全症例とも同 寄生虫症の自覚症状はなく，発生頻度としては男性 $53 \%$ 女性 $47 \%$ で男性に多く，年令的には10才台 $6 \% ， 20$ 才台 $27 \% ， 30$ 才台20\%，40才台20\%，50才台27\%というよう に青壮年層に多く見られる。組織学的には虫卵は虫垂各 層に存在して，一般に粘膜下風に最も多く，他の圈には 比較的少なく散在性或は集団性に分布されている。虫卵 の内容は変性したものから石灰化までの各種のものが認 められ，粘膜固有層には欠損，萎縮，漬湯形成等がみら れる。

虫畉の比較的新しい場合には多核白血球及び好酸球等 の細胞浸潤が多く, 又異物性反応として虫卵の周团並び に畉款内に侵入した異物巨細胞を認め, 更に卵殻のみと なつたものも多数に見られる。虫卵が古くなる亿従つて 結合織の增殖を主とした増殖性反応が強く，次第に虫畉 を取り团む大きな線維性結節を形成する。筋層に虫卵の 介在する場合には, 卵周囲の結合織の增殖に伴なつて, 筋線維の圧迫萎緛及び断裂等が認められる。

我々の症例では, 虫卵は陳旧性のものが多く, 比較的 新鮮例が 2 例であつたが，乙机らの検索結果では，虫畉 は閒脉系に介在するものの一部として認められるもので 虫垂炎発生の一次的原因というょりも卵の介在による增 殖性変化により, 虫垂内腔の狭窄, 局所の循瑷障害, 組 擮の脆弱性等により虫垂炎が促進され易いと考える方が 妥当のように思われる。又, 同寄生虫㱏の減少した現在 でも，約15\%に発見されることは，尚流行地に於いては 切除虫垂につき可能の限り組織学的検查を行つて, その 対策を講ずべきものと考える。

\section{I-104 老年期の虫垂炎について}

金沢聖霊病院
中 隆, 新野 武吉
O倉西 久雄

老年期の虫垂炎はその特性上，早期手術が望ましい。 従つて, 容易かつ安全な麻醉法が求められているが、現 在でも尚局所浸潤麻瘦が大きな割合を占めている。われ われはそれに代るものとして, 就眠量程度の静麻肪と笑 気を使用して，笑気の無痛期を利用する方法を試みて好 結果を挙げているので，2〜3の例を引用してわれわれ のいう笑気アナルゲジーを紹介した。

\section{II-105 虫垂癌の一例}

\section{慈生会病院外科 \\ 加藤 模、和 哲郎}

本邦交献上虫垂の原発性腫煬は種々あるが，その中虫 垂癌は16例である。吾々も虫垂瘤と思われる一例渚遇 した。

症例：65才古，現病歴：昭和35年 5 月急性虫垂炎とし て手術を受け，腰麻ショックのため，虫垂は切除されな いで終つた。その後も時々回盲部痛あり，便秘勝となる 37年 9 月腹部膨満，悪心あり，手術㗪痕部に抵抗部を触 れ精查をすすめられている。

38年 1 月22日から腹痛が強まり，腹部は膨满し、嘔叶 も加わり，1 月25日当方内科需診、回盲部演兼腸管滤着 障碍として入院した。1月31日手術施行, 手術可見: 手

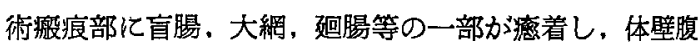
膜の盲腸部に接する外側及ひ下方，その後内方は腸骨窩 部にて腸腰筋縁, 輸尿管に接して, 後腹膜腔に浸潤のあ る小手拳大の腫瘤を右半結腸切除の下に摘出す。腫場の 肉眼的所見：盲腸の後外側から迴腸末端の漿膜に密着し た瑟卵大の腫場にて、虫垂の原形はなく、盲腸粘膜の虫 垂口と思われる部之，廻腸末端の一部粘膜とに，各々瘦 性浸潤と思われる変化あり，バフレン氏㲔は異常なく， 2 個の所属淋巴節転移と思われる所あり，その他の転移 は認めなかつた。病理所見：円柱上皮癌。以上の諸点加 ら虫垂に原発した腺癌と診断した。

5 月下旬, 癌の再発を認め, 6 月中旬国立病院へ入院 し、Co照射を受け，7月当方へ:再入院した。波下への 転移を試験切除し、鏡検により癌細胞の変性を認め、臨 休的にもその効果を或る程度知り得た。今日尚存命中で あるが、重症である。

本邦報告16例について見るに，その初期に急性虫垂炎 或は盲腸周团膿湟の病状を現わするの多く，手術は必ず 
しも一期に回盲部切除，或は右半結腸切除が行われてい ない。その半数近くが術後間るなく死亡している。以上 原発性虫垂㾔と思われる 1 例を報告した。

\section{Iー106極めて稀な、亩腸原発ホジキン肉睡の 1 治験例}

$\begin{array}{crl}\text { 大阪厚生年金病院外科 } & \\ \text { 堀 } & \text { 觜. 永友 } & \text { 知英 } \\ \text { 朝野 } & \text { 登. 黒瀬 寅次 } \\ \text { 井上 } & \text { 忠雄. 白井 } & \text { 忠義 } \\ \text { 吉岡 } & \text { 䛨二. 水野 } & \text { 進 }\end{array}$

症例は 58 才の男子, 下腹部疝痛様発作を主訴とし、 2 ケ月間に約 $4 \mathrm{~kg} の$ 体重減少, 粪便潜血反応強陽性.レン トゲン所見その他より，盲腸癌と診断し，回盲切除術を 施行したが，腫瘤は，盲腸壁より腸管内腔に突出し、卵 球形、瑟卵大で、病理組織学的に、ホシキン肉嗹と確認 された。2〜3の局所腸間膜リンパ節に転移を証明した が、表在リンパ節缠脹, 肺。縦隔その他遠隔転移は証明 しない,術後6ヶ月に満たないが, 現在再発、転移の徴 候もなく，元気䎲復職している。

ホジキン病については，遇煬か炎症か、いまだにその 本驡に関して論議の渦中にあり,従つて,明確な記載をも とにして、消化管ホシキン病の実数を把握するととは团 難であつたが，少くとも，本症例の如き，盲腸に限局し， しかる腫瘫形成の形で切除された，ホジキン肉腫は，極 めて稀であるてとを，2〜3の文献徵して紹介した。

即5. Allen らは, 79例の腸管悪性リンパ腺腄切除例 中，大腸におけるホジン肉腫は，わずかに 1 例をみた 亿すざず，Portman は1954年 までの 交献集計により 106例の消化管ホシキン病を集めているが，大腸には7 例, そのうち、尰瘤形成型は、結腸に 1 例と, 直腸の 2 例のみで，盲腸に見た 3 例は何れも浸潤型であつたと記 している。

尚，本院開設以来満10年間に，当外科で扱つた悪性腫 嫁総数は1127例. うち胃腸管の悪性腫湟 791例。そのう ち, 肉瘇は，胃に 7 例，腸に 4 例で，腸の 4 例は，細網 肉腫 3 例、ホジキ肉腫 1 例であつた。

\section{座長 林 田 健 男 教授}

\section{II－107 消化管内アルコール酸醉の 2 例}

東京警察病院外科 若林 利重, 溝田弘

$$
\text { 長谷 光一, 新谷 義克 }
$$$$
\text { 吉川一彦, 下島弥 }
$$

沼津市杉山病院 山村 沉

第 1 例は33才男子。昭和 35 年 10 月腸結核による空腸起
始部の穿孔で穿孔部閉鎖術を行ない，急性腹膜炎は治傯 したが術後腸狭窄の症状が現われ，X線検查により胃十 二指腸にバリウムの停滞を認めた。胃腸吻合術により狭 咋症状はなくなつたが, 更に約 3 ケ月たつて食後酪酊す るようになり，米飯 2 杯以上とることは出来なくなつ た。酒は全然飲まない思者である。検查を拒み，他の病 院に移つて胃切除をうけ酷醇店状は消失した。第 1 回の 手術後ペニシリンの大量投与と SM, PASの化学療法を 6ケ月施行した。

第2 例は28才女子。現在までにうけた手術は合計12回 その間一貫した症状は嘔吐, 腹部䤃満, 腹痛と高熱の持 続である。当院で行つた手術は第10回目からであり，先 ず回腸横行結腸吻合部狭窄の診断で吻合部を合め拡張せ る回腸切除。次で胃空腸吻合部の輸入脚への逆流を認め たのでRowxのY型吻合に直した。最後に回腸横行結腸 側々吻合部Blind loop syndrome の診断で 2 つの盲管を 切除した。しかし相変らず同様の症状。約 7 年間との症 状は持続，その間使用した各種抗生物質の量は莫大なる のである。当院で行つた第 2 回目の手術のあとで偶然此 物にアルコール峊のあるととに気付き，また食後 1 時間 位たつと動悸, 頻脉, 頭痛, 顔面紅潮, 眼球結膜の充血 発幵などの症状の発現を認めた。胃夜よりCandida albicansを分離。乙の菌のアルコール生成は $1.3 \%$ ，血中

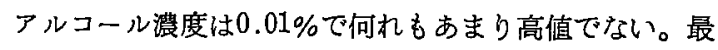
近マイコスタチンを使用しはじめ目下経過観察中。頑固 な症状が持続しながら全身状驡は殆どおかされていな い。

第 1 例は諸家の報告例と同じく典型的な消化管内アル コール醴醇による酪酊症である。

第 2 例は最初胆道系疾患ではじまつているが，胃晹管 の度々の手術にもかかわらす腹部膨満をくりかえすもの で体質にも関係があるように思われるが，これと共に抗 生物質の長期投与が真菌の増殖に好条件を与えているよ うに思われる。との症例の主病変は消化管Candida症で アルコール醗醉は附随的症状のようである。

\section{㯰 問}

酪酊度はどの程度ですか。

\section{東大分院外科 林田 健男}

呼気のアルコール臭や血中漲度はどの位ですか。

回 答

東京警察病院外科 若林 利重

(1) 酩酊状態は所謂醉つぱらいに相当する。食後 1 時間 位たつと醉つておきておれずねむつてしまう。患者は元 
来酒を飲まないので醉うとむしろ気持が悪くなるとい う。昼食には酔うと仕事が出来なくなるので米飯をとら ないようにしている。酔つてあばれることはない。

(2) 血中アルコール濃度は第 1 例は㭧者が検查を拒んだ ので残念ながら出来なかつた。第 2 例では0.01\%であま り高くないので䣲酊する程度ではない。勿論女子であつ て酒を飲まない患者である。

\section{IIー108 胆管毫腫を思はせた消化管重複奇型の一治 験例}

日赤中央病院幕内外科

$\begin{array}{rr}\text { 幕内 } & \text { 精一, 渡辺 } \text { 昇 } \\ \text { O内田 } & \text { 法光, 高野 } \\ \text { 章 }\end{array}$

最近, 私共の経験した乳児十二指腸部のduplication の一症例に就き，多少の文献的考察を加えて報告する。

症例は，手術時生後 1 ケ月の男児で, 生後 2 日目より 噴水状吐乳を繰返し, 生後 2 週目に本院小児科に入院し た。家族歴及び分婏に異常なく，排便正常で，入院後10 日目に外科に転科した。

転科時所見：右上中腹部に表面平滑硬の瘇癌を触知し 移動性なく，検査成績では黄疸がみとめられるのみであ る。

レ線所見では，腫瘍により十二指腸を除く腸管が左方 及び下方に圧排され，十二指腸のみが腫㴼の前右方に大 きく鷗乗している像がみとめられた。以上の所見より後 腹膜より発生せる玨腫の診断で生後29日目に手術を行つ to

手術は右 Transrectalschnitt で開腹し，肝，胆㢣を 検するに異常なく，膵頭部が前上方に圧排されて居り， 十二指腸はその後面に存する腫藘により右前方に偏位し 延長していた。腫瘤は十二指腸との境界でやや陥凹する のみで，色調は之と同一で緊張せる樭腫であつた。一次 的に十二指腸之吻合を行い，術後経過より二次的に根治 的切除を行つた。患者は術後 6 ヶ月健康に発育して居る。 手術的診断は病理的診断と一致し, 病理学的所見は腸管 と同一の像を呈していた。

Gross の68例, 森田等の25例中, 各 4 例及び 1 例のみ がみられる十二指腸部の duplication はその診断か湛だ 困難ではあるが，開腹時所見によれば比較的容易であり 又その治療もかかる翼腫状構造のものでは，単に腸管と の吻合を行うよりも切除した方が，予後良好であると考 えられる。

以上, 私共の行つた duplication 根治術により, 爾後 通過障碍もなく, 健康に発育している1例を得たので報
告した。

\section{質 問}

東大分院外科 林田 健男

十二指腸のどの部分において切除の難易があると思い ますか，幕内先生すおられるようですがいかがですか。

\section{回 答}

東京日赤中央病院幕内外科 幕内 精一 Duodenum $の$ Duplication は筋層が十二指腸管と交叉 して入りまじつているので全切除は出来ないで丁度覩室 切除の要領で手術をすればよい。

次に鑑別診断が興味ある。新生児で黄疸があつて，右 季助下部に腫瘤がある時には先ず胆管垔腫を考えるが， との場合には生後 4 日目から黄疽が発生する。とてろが 本突患者は 7 日目から発生してきている点がてとなるの

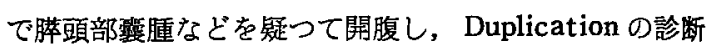
を確定し得た。

\section{II－109 巨大なる腹膜後部畽瘍の 2 治験例}

東邦大学小平外科 三竹 俊雄, 南 孝雄 ○柳田 謙蔵

東邦大 第一病理 西井 啓二

最近我々は巨大な腹膜後部腫瘍の 2 例を手術的に全治 せしめ得ましたので報告致します。

症例 1：19才男子，3才の時腹部膨隆に気付き，6才 の時某医にて手術施行し腹部大動脈に慜着強きためその まま放置され深部治療を受けています。諸検查の結果， 腹膜後部腫湯の診断のもとに手術を行ないましたが、剔 出標本は左腹膜後部に発生し, $30 \times 25 \times 17 \mathrm{~cm}$, 重量 56 $20 \mathrm{~g}$ で，大きさは本邦報告例中 2 番目のものでありま す。肉眼的には一部実質性,一部㖶腫状を呈する隀湯で 実質部には 2 個の婳瘤，両側上下肢と思われる所属物及 び胃腸管等が認められました。装腫内には兏白色豚脂樣 凝固物が毛㰮と共に充満していました。組織学的には外 胚葉由来の表皮，爪，汗腺脂腺及び脳組織があり，内照 葉由来の消化管及び中胚葉由来の骨, 軟骨, 結合織及び 平滑筋線維からなり，3 胚葉性のテラトーム様腫晹でし た。術後 2 年現在なお健康であります。 症例 $2 ： 38$ 才男子。 2 年前より腹部膨隆，頜血，血尿を 訴えています。検查所見では負血，血尿以外特に異常所 見を認めません。剔出標本は $38 \times 18 \times 28 \mathrm{~m}$, 重量 $4500 \mathrm{~g}$ 左腎下極に瘾着し，全体に被膜で被われ，前面は平滑で ありますが数条の線維索を認め, 後面は後腹膜の軟部組

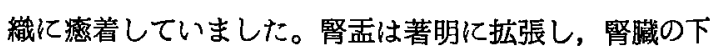





軟な実質性部と，嚄胞状部の 2 部より成り，露胞中には 大量の鮮血及びやや古い凝血塊が充满しています。組織 的に震腪壁内面は，腎杰或は尿管の上皮々類似構造を有 し，又移行している部も見られます。即ち細胞は多角形 明性で, PAS, 脂肪染色陽性, ムテカルミン陰性で, 所によりビマン性又は密在性で，多核巨細胞及び䇒肥厚 の著明な多数の血管を含んでいます。尚一部には clear cell carcinoma 亿多少類似する細胞で被われたた複雑な 組織像を呈する部すあります。又一部には多核巨細胞及 び Xanthoma 様細胞を含む小肉 芽腯様部分がありま す。腫瑒中心部は, 出血, 変性, 壊死に楩つていますが その周辺では脂肪顆粒を有する嗿食細畇及び好中球浸潤 が著明であります。腫堭細胞の多形性から見て悪性腫湯 像を思わせる部分がありますが，しかし完全に被包され 周囲組織への転移や浸潤も認められません。

以上の如く, 病理学的に非常に興味があり, 又非常に 診断困難な症例でありますが，おそらく- metanephric stage から出た腫掦に近いものと思われます。なお，患 者は術後 2 年 2 ケ月現在健康であります。

追 加

東大分院外科 林田 健男

最近小児外科で後腹膜腫掦は Grors 達もいつておる ように，側腹部から前腹壁を横切つて横切開で行います と、反对側まで成長した巨大なものでもたしかに楽に手 術出来るようです。

回 答

東邦大小平外科 柳田 謙蔵

皮㣂切開は，初正中切開を行ない，摘出不能のため 胼部より左横切開を追加しました。

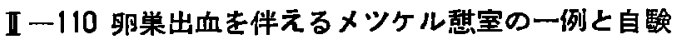 例四例を含めて本邦に於けるメツケル覟宝の 統計的観㲾}

福岡市香椎外科 清成 正智

自験例 4 例を含めて本邦に於けるメッケル想室 316 例 の統計的観察を試みた。

発見頻度は大体 $1 \sim 2 \%$ 前後であるが, 開腹手術例で は0.5\%前後である。

男女の比は $2 \sim 3$ 対 1 で男性に多く，年令は20才以下 の若年者が大部分である。

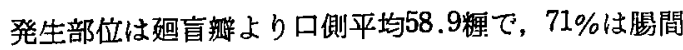
膜附着反対側遊離粶に，18\%は腸間膜附着側に，11\%は
腸管側壁に存在し, 想室の長さは平均 $3 \sim 4$ 糎であつ た。

異所的組織の迷入では胃粘膜の存在率が高く次で勝組 織の存在率が高かつた。

術前診断は虫垂炎及び腸閉塞が最も多い。メッケル稳 室の病的機転として頻発するちのは腸閉塞, 腸出血, 頽 室炎等であるが，本邦と海外の文嗝とでは著明な差異を 示している。

本邦では腸閉塞が $59.8 \%$,腸出血3.5\%で外国では腸閉 塞 $26.6 \%$ ，腸出血39\%となり逆になつているが，その原 因が何処にあるかと云う事は今後検討する必要がある。

腸出血は一般に年少者に多く，小児と成人とでは腸出 血に対する抵抗の差にもよるであろうが，小児側では多 くは初回の出血で重篤な貧血症状を示す場合が多いとさ れる故，小児の䨘血例ではメッケル覟室も念頭に入れて 診察する必要がある。

メッケル秘室の術前䛦断は虫垂炎が最も多い事よりし $\tau$ ，虫垂切除の際には廻腸末端部をも精査する事が大切 で、その為にも皮䖉切開をいたずらに小さくする事はい ましむべき事である。

\section{IIー111 外科的腹部疾患と諨診された汹尿器科疾患に ついて 横浜市立市民病院外科 渡辺 三作，洲畸 兵一 針谷 宏, 親松 常男}

腹部の外科的疾患々必尿器科突㭧は, その解剖的関係 から誤晾され易く，往々にして誤診例に遭遇する。我々 は，炤和35年 10 月以来。外科的疾思として，当科を訪れた 患者中，50例の䎵尿器科患者を経験したので報告する。 その内訳は，尿管結石 18 , 遊走腎 7 , 前立腺肥大 4 , 膀

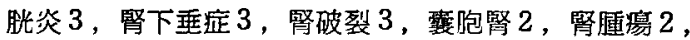
腎結石 2 , 副睪丸炎 1 , 尿道狭管 1 , 急性腎炎 1 , その 他 3 である。診断確定前の病名は，急性虫垂炎 15 , 腸療 着 2 、イレウス 1 , 胆石 3 , 神経定 1 , 便秘 1 ，ヘル二 ア術後障碍 1 , 胃漬瘍 1 、その他である。次に以上の中 特に代表的な数例をあげる。症例 1 ，23才男子，工員， 昭和38年 1 月 9 日, 腹痛, 悪心嘔吐のため, 某医にイレ ウスと診断され，手術を受けた。糸コンニヤクが大腸に つまつていたと云う。術後も路痛は軽減せず，2 2 月後 腸湶着と云われ，再開腹を受けた。その後も腹痛軽減せ ず，発作的に增強する。左瓜管結石であつた。

症例 2,29才, 男子, 自衛官

2 年前. 右下腹部痛あり，虫垂炎と診断され，虫垂切 除を受けた。その後も，同栏の疼痛がつづき１年後， 
腸瘾着として，再手術が行われだが、疼痛は依然軽減し ない。右尿管結石であつた。

应例 $3 ， 37$ 才, 男子, 会社員, 約 1 年前加食後 $2 \sim$ 3 時間で心简部痛が起る。 3 日前から, 右下腹部〜上腹 部に及ぶ激演あり。嘔吐頻回, 腹部膨隆、苦閶状。胃穿 孔として送院されて来た。右尿管結石及び左腎結石によ る急性尿毒症であつた。

症例 4，19才，女子，事務員，8年前右下腹部痛で虫 垂切除を受けた。その際、後腹膜に癌?があると云われ た。その後も, 間歇的に腹痛及び腹部隀瘤が出現する。 督下垂による水餐症であつた。

以上，検尿を怠つた許りに正確に診断を下し得なかつ た㱏例を釈介，緊急の場合でも，検尿位は行うべきであ るととを改めて強調した。

追 加

岐阜市村上病院 村上 治朗

逆であるが虫垂穿孔が左先天性巨大雫水腫のために誤 診されていた 1 例を報告した。水腫珡は全腹腔を占領し 胃、腸は右上方に圧排されていたので 2 人の外科医に 2 回手術されたのに，穿孔虫垂が見逃がされていたのであ る。

\section{I-112 結腸・直腸癌の統計的観察 第 I 報 新潟大外科 大森 幸夫. 山宮 克巳}

昭和26年以降、我々の教室で経験した結腸直腸癌の遠 隔成績を見ると，5年生存率は $44.6 \%$ であつた。（切除 率59.4\%，回答率94.5\%) 乙れを癌腫の発生部位別にな がめると直腸癌では $49.1 \%$ ，左結腸癌では $53.3 \%$ の 年 生存率が認みられるに対し，右絹腸癌では $27.3 \%$ と遠隔 成績が格段に不良であつた。との様に，右結腸癌の予後 が悪い事実は如何なる要因によるものかを追究した。

先ずリンパ節転移を鏡検した所，左結腸癌及び直腸輹 ではリンパ節転移率が夫ん25.4\%，48.4\%であるに対し 右結腸では $60.0 \%$ と著しい高率を示していた。しかも右 結腸癌では，転移陽性リンパ節が二次。三次リンパ節群 にも可成高率に認められた点が注目された。

次に瘦病柴の腸壁深達の程度を見ると、槳膜に達した ものが左結腸癌で， $69.2 \%$ ，直晹癌で $47.5 \%$ でるに比 ベ, 右結腸痁では83.3\%の高率であり, 又浸潣性発育の 傾向の強いものが多い。一方. との深達度. 浸潤度とり ンパ節転移の関係を見ても，右結腸癌では壁深達度が墏 膜以上に及んだ場合 $100 \%$ \%ンパ節転移を生じている が、他の部位の痁では漿膜以上の深達度を示していても リンパ節転移を認めなかつた症例を若干認めており，両
者の間でリンパ䬦転移の出現に明らかに差異のあるとと が知られる。

更に癌病栄周包間質の態度を見ても，左結腸癌や直腸 癌では間質反応強度例が夫々 $30.8 \% ， 36.7 \%$ であるに比 べ右結晹㾞では17.6\%に認めるに過ざない。他方斯万間 質反応溞度群ではりンパ節転移率低く，5年生存率良好 であると言う事実から，右結腸激に於ける微弱な間質反 応の態度は，右結腸癌の予後不良である大きな原因の一 つであると考える。

以上の如く，右結晹㽟では高度の壁浸閵深達を起し， 広汎なリンパ節転移を起す傾向が大で，而も周辺間賈に 於ける防㮏的反応にも乏しいものが多いことが知られ， 予後の改善の為には早期発見はもとより出来る限り広籘 团の所属リンパ節廍清が必要と思われる。

诈 問

痁研外科 山田肃

右側結腸瘦の予後はわるいとうかがいましたが、主と して採用されている術式については如何でしようか。

回 答

新渴大外科 大森 幸夫

右結腸演の局所再発については，理論的には，腹部大 動眽周包. 即ち第 3 群以上のリンパ節群に再発して来る ととが考元られます。私共の所ではまだ右結腸癌切除後 の再開腹例, 及び剖検例の詳細な検討は致しておりませ んので，理論的の予测について申し上げます。

回 答

新渴大堺外科 山宮 克巳, 大森 幸夫

1) 大部分のもので，右半結腸切除兼リンパ節庮清が行 われています。

2 ) 再発の問題に対する検討は未だ充分行つていません が, Para-aortal のリンパ節再発が最も多い様䎲思われ ます。

追 加

東大分院外科 林田 健男

只今拝見した表で大変印象的と思うととは，粘膜又は 粘模下層までの早期癌に淋巴腺転位がないととです。ご 承知の通り最近の内視鏡の発達によつて, 胃演も同しく 粘膜又は粘膜下層までの早期癌は容易にみつかり、てれ らはやはり殆んど淋巴腺転移がない。この意味で食道癌 も含めて粘膜症の段階での早期診断を結腸直腸癌に強く のぞみたいものであります。 


\section{座長 村 上 治 朗 博土 \\ I-113 直腸及び結腸癌の姑息手術検討}

渻研外科山田肃, 田村 竜男

西 满正, 深見 敦夫

癌研外科に抢ける大腸癌姑息手術例 106 例の検討を行 つた。

性別については，姑息例が結腸に稍々多く，直腸に稍 少いように思われるが，年令別，遗伝関係，等に特に有 意の差は不明であります。症状につきましては，根冶手 術例之踓も可成り進行した症例が多いので、而者仁あま り差異はないのでありますが、やはり結陽瘦では体重減 少 $(70 \%)$ ，腹部膨満 $(60 \%)$ ，腹痛 $(76 \%)$ がもつとも多 く，面腸においては体重减少 $(83 \%)$ ，テネスムス $(81 \%)$ 便粦滞感 $(77 \%)$ ，粘液又は膿汁排泄 $(73 \%)$ ，出血 (73\%) 等を主としております。病悩期については姑息例におけ ろ延長は明らかではありません。

次估息手術の原因を見ますと肝転移の $43 \%$ がすつと も多く，播種性転移の $30 \%$ ，周囲臓器浸潤の $28 \%$ がてれ


性転移のもつとも多いてとと対称となつています。 次に発生部位を見ますと肝転移は右結腸に少く（姑息 例の $26 \%$ ，全例の $7 \%$ ），左結腸に多く(姑息例の $56 \%$, 全例の14\%)，直腸骨盤部に更に多く（姑息例の68.0\%， 全例の $16 \%$ ）直腸膀大部以下では姑息例の $36 \%$ ，全例の $6 \%$ となつておるのに対し，播種性転移は右結腸に多く （姑息性の68\%，全例の19\%），左結腸（同28\%，7\%） 直腸骨艒部（同 $27 \% ， 7 \%)$ 飞少くなつています。又周 囲藏器浸潤については右結晹に稍多く(姑息例の $32 \%$,全 例の $9 \%$ ), 左結腸（同 $22 \% ， 6 \%$ ），直晹骨盤部（同 27 $\%, 7 \%$ )，直腸膨大部以下 (同 $30 \%, 5 \%$ ) 江減少して います。又リンパ節転移が姑息手術の原因となることは 右結腸に少く（姑息手術の $5 \%$ ，全例 $1 \%$ ），左結腸（同 $17 \% ， 4 \%)$ ，直腸骨船部 $(18 \% ， 4 \%)$ ，直腸膨大部 (30 $\% ， 5 \%$ ）にはより多くなつています。次に原発巣の肉 眼的分類は，肝転移例任限局性発育型少多く $(61 \%)$ ，浸 潤，播種例には中間型，浸潤型が多いのであります。こ れは胃癌の肝転移例にも限局性発育型少多く，浸閏，播 種性転移例には浸潤型の多いととと対応しております。

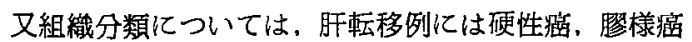
はなく、腺腔形成が箸明でその大きいちのが多く、Adenocarcinoma Papillotubulare 乃至 Adenocarcinoma macrotubulare 20例, Adenoca. mesotubul. 6 例 Aaenoca. mierotubul. 7 例, Adenoca. Scirrh. 0, Adenoca. gelatin。0である。浸潤、播種例には各型 が散在している。次に Dukes 分類でその進展度を見る
と大部分がC群で，A群 1 ，B群 4 が見られた。又原発 巣の全周発育例と壁在例の頻度は肝転移例では両者が略 等しく，播種浸潤例には前者が多い。

次に姑息手術症例の予後を調査したところによると， 約70\%は 1 年以内に死亡しているのであるが，1 年以内 の死亡者には非切除例が多く，3 月以内に死亡した21例 では切除例は 4 例のみであるのに，1 年以上生存したも のには切除例が多く、特に 2 年以上生存した 7 例は全例 切除例であつた。即ち局所の条件が良い場合は切除した 方がよく、吻合、人工肛閏に止めざるを得ない上うな症 例には長期生存を期待出来ない。

\section{I -114 慢性便秘症の外科的適応に関する臨床的実驓 的研究}

$$
\begin{aligned}
& \text { 神戸医大第一外科 } \\
& \text { ○植松 清, 姉崎 越夫 } \\
& \text { 坂東 省二, 藤本 疆 } \\
& \text { 豊原 大雄, 伊藤 顕 } \\
& \text { 高雄 清人, 大西 則男 } \\
& \text { 山口 勝敏, 布留 容一 } \\
& \text { 佐古 一穂, 川北 博明 }
\end{aligned}
$$

一般開腹術後に㴔むべき腸管瘾着又は器質的原因がな いのに慢性便秘に悩まされる患者の数は比較的多い。こ れらの症例を集めてその結腸運動をレ線観察しながらブ スコパン、ワゴスチグミン等の相反する作用を有する薬 凪を20\%ブドウ糖に混じて静注すると、ブスコパンでは 腸の弛緩をワゴスチグ シンでは腸の緊張及運動六進を示 すのが普通であるのに反し，ブスコバンでは反つて腸の 興舊を来し、ワゴスチグミンに対する反応力は弱い事が 観察される。この様な逆転現象は結腸全体或いは半結腸 化認められるが，回盲部或いは上行結腸に最も多く局在 して観察される。この逆転現象を示し然もその現象が局 在する結腸を切除すると便秘は好転する。逆転の理由を 解明するため，我々は症例が若い婦人に多い事之症状の 増悪方明らかに月径周期に関係する場合がるられ，てれ にE.P.ホルモンの適当な投与で慢性便秘が纊和される 事実から，開腹術後の内分泌失調が関連しているのでは ないかと考元，次の実験を行つた。

踓犬の脳下垂体を10日ないし2 週間前に剔除し副腎, 卵巣，甲状腺を 2 日前に除去して，脱ホルモン犬を作成し

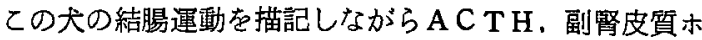
ルモン, 黄体ホルモン、卵胞ホルモン等を夫々単独に投 与した後、てれにブスコパン、ワゴスチグミンを投与し て結腸の反応を観察すると，脱ホルモン犬ではホルモン 投与しないときは逆転反応が証明される。とれは一応人 
に見られるものに酷似している。又，ての現象を打消す ために最も有効なホルモンは卵胞ホルモンであり，その 作用は現在分析中である。慢性便秘症の中には絬腸がブ スコパンで逆に興鹪するパターンがあり，それが局在す る時は切除により症状が好転すること，又との現象には 性ホルモンが関係する事を報告した。

追 加

德島大学 田北 周平

逆転現象が動物実験では認められるてとがあるが、そ れと同一のものであるかどうかは私にはまだ判らない。 種々の方向から演者の事実が確認されるとすると，興味 ある現象であろうと思う。

\section{追 加}

神戸医大藤田外科 川北 博明

慢性便秘症におけるブスコパン逆転現象が或る程度性 ホルモンに関係する。との点を動物実験に於いて解明し 本毄性慢性便秘豦に対する研究の緒口を開いたように思 う。

諸先生ので注意を喚起したい。

I一-115 大腸切除術施行症例の検刢，特に腸ゆ着症と の関係について

青森労災病院外科

○福田 幸雄, 今岡 健郎

われわれの大腸切除症例は68例で，うち回盲部切除21 例, 結腸右半切除36例で大部分を占め. 主として右側腹 部の笑患に対して手術か行なわれた。その手術成績は回 盲部切除, 治ゆ, 軽快20例, 結腸右半切除治 例で比較的良好な成續をおさめた。

$\mathrm{S}$ 字状結腸切除，面腸切除は合計11例の少数であるが 不変, 悪化 4 であまりよい成績ではない。

㱏例別に検討してみると，所調晹り着应と診断をうけ たものは56例あるが，てれらの症例は虫垂切除後のもの が大部分で，次いで婦人科手術後のものである。との手

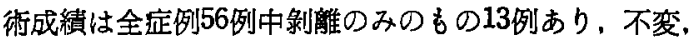

悪化 4 例で予想したより悪い成績である。

回盲部切除及び結腸右半切除が治ゆ，軽快多くすぐれ た成續である。腸ゆ着症と診断をうけたもののなかには 手術所見上, 腸ゆ着上りも目腸移動症, 結腸下垂. 過長 等に基因する障害と思われる症例が前者33例に対して, 後者23例と含まれている。

われわれは腸ゆ着と同時に他疾患があればてれに対し ても積極的に手術を行つている。
次に腸ゆ着症と診断されたものが吻合病て腸切除によ り経過順調であつた症例を揭げ，腸り着症の手術適応決 定に慎重なることを強調した。

次に結腸の移動，過長，下垂等の疾患，あるいはそれ らに由来する慢性便秘症の手術成結は術式別には格別の 差はないが，16例中 4 例の不変があるので適応決定に慎 重を要する。しかし便秘の軽快は全例に認められた。 大腸癯及び回腸末端炎等の手術成績は良好であるが， 9 例中直腸癌の 1 例のみ再発し悪化している。

\section{犋 問}

京府医大河村外科 上田 泰章

1) 慢性便秘症例の手術適忘についての術前検查につい $\tau_{0}$

レントゲン検查は注腸か或いは経口によるものであ るか。

2 ）腸管切除範囲は如何なる基準で手術時に決定されて いるか。

3）切除腸管神経叢の状態はどうか。 我々の教室例では大多数がアウェルバツハの神経㥅 の著明な変化を認めていない。

回 答

青森労災病院外科 福田 幸雄

1) バリウムの経口投与を行つて術前に右結腸型，左結 腸型等の適応をきめる。そのほかに肛門から注晹バリ ウム検查を行つている。

2 ）行つていない。今後実施する予定である。

\section{座長啠問に対し}

東大林田 健男

慢性便秘定の外科手術適応のととと思いますが、同し バリウム検査でも経口的に，又は経肛門でやる場合でも 大変慎重でなければなりません。同じ経口投与でも思者 を色々な条件の下に必要に応じて 5 回でも 6 回でもくり 返して罹患部位即ち切除部位を決めるべきであります。 又, 神経細胞の変化でも拡大腸管ではその数や周囲組織 の変化との関係でも見方も仲々判定しにくい。筋電図の 方法もあるがてれとて全体としての臨床的にみた充分 な外科適応の方法とはいい切れない。結局種々な方法で case by case で決めていく方がよいという現状であり ます。

I一116 早期人工肛門造設により著勃を見た溃瘍性大 腸炎の一例 
名古屋市大 第 2 外科 服部 節朗 我々は最近早期人工肛門造設により著効を見た漬湟性 大腸炎の一例を経験したので報告する。

应例: 32 才 男子

主訴：頻回の血性下峲

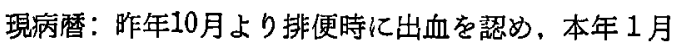
24 日腹痛と共に 1 日 10 回位の血性下脷を来し 2 月11日入 院。

入院時所見：腹部は脳下部から左方にかけ区痛を認 む。臨床検查成績は貫血と低カリウム血症を認め万他異 常なく筫便培美も赤莉菌は陰性である。乙線検査では $\mathrm{S}$ 字状結腸の過長 Haustraの欠除, Spicabildung, lead -pipe を示し. 直腸鏡検查では数ヶ所に漬陽を認め，粘 膜は全体に充血，浮腫著名で点状出血を所々に認む。以 上の所見により清場性大腸炎と診断したが入院時より 1 日100 350ccの出血があり大量の輸血, 止血剤にも反応 しないので入院 5 日目に左結晹曲より $5 \mathrm{~cm}$ 口側の横行結 陽に二孔性の人工肛門を造設し. 術後 7 日目に開放性と し、その䢸門側盿置腸管を連日アドレナリン加生理的食

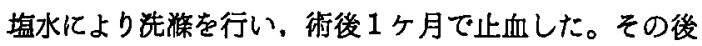
はアズノール液の肛門側脑置晹管内注入とサルファ刘。 抗生物質, 副督皮質ホルモン療法の併用にて術後 3 ケ月 で軽快退院す。

考按：本症の原因には種々の説があり，特異的な療法 はなく根治せしめる事は極めて困難である。我々の症例 はレ線上,下行結腸以下に限局していた為,横行結腸に人 工肛䦎を造設し前述の洗淮法を行い奏効を見た。臨床的 には横行結腸には変化はないと考元たが組織学的には病 変が進行していたが，それにも拘らず病変を消退せしめ 得た。之は比較的早期に人工肛門を造設したためと思わ れるので，漬湐性大腸炎では早期に一応試みるべき方法 と考え敢て報告する。

\section{I-117 疛瘻の成因に関する再検㣙 第一報 自衛隊中央病院外科 松原寛. 布施 為松 小沢 啓邦}

庤禤と結核性疾患の関連性は古来璉々と論議され，現 今です胸部レ線を始めとして一連の結核を対象とした術 前検查がよく行われている。而しながら我々は，次に申 し述べる諸点から，寿霓の結核説には，少なからす疑義 をるつている。

即ち，入隊前㳊重なる身体㭘查を受け，更に充分な ろ煡康管理を受けている自衛官でも。陆瘦の発生は少く なく，一般社会人とほぼ同率に認められ，全肛門疾思の
約 $1 / 4 の$ 多さに達している。又ッ反応陰性者に於ても，疛 瘦の発生は少くない。

我々は 140 例の症例に於て, 病理組織学的に精查し, 結核性病変の有無を検索したが，一例も認めることが出 来なかつた。ただ混合感染などを譛める症例ではかなり の頻度に異物性巨細胞を認めた。疑わしいるのをいれる と, $25.8 \%$ であつた。

以上の様な諸点加ら，現在我々が浀週している痔瘦で は，従来云わ机ている様な結核成因説を支持する根拠は 極めて乏しいのであるが、考えなけ机ばならない点もあ ろ。

(1) 結核が難治性であつた時代に於ける痔瘦に接してい ない。

(2) 仮偘核性病変があつても，非特異性炎症が混在し ていると，結核性病変を確認するととが困難である。

(3) 膿汁や肉芽病変中の細菌の培養.さららに動物への 接種実験を必要とすること。

我々は現在迄50例に培養を試み、1 例に結核菌を認め た。

(4) 最後の問題は, 庤掼の発生機転の解明がある。

以上の諸点については，今後も追求したいと思つてい ろ。

追 加

岥阜村上病院 村上 治朗

寅者のご研究は，従来の寿瘦結核説が誤りであるとい う結論ではなく，今日の清瘦はかつてのような結核性の ものはすくないといわ斿る方にもってゆかれるのが罗 当なのではないか。

\section{Iー118 肛門外科手術後に発生した特発性道腸大出血 の一例

$\begin{array}{lll}\text { 九段坂病院外科 } & \text { 永島 } & \text { 能衛. ○後藤 雅久 } \\ & \text { 柿沢 } & \text { 弘基 } \\ \text { 東大分院外科 } & \text { 細田 } & \text { 泰元 }\end{array}$

37才，男子，手術前血小板，出血時間など正常で特に 出血性素因を認めない。腰椎麻醉下にミリガン法によつ て疛核切除術を行なつた。術後7日強い腹圧をかけてよ うやく多量の排便があつたが，その翌日突然約 $600 \mathrm{cc}$ に も及ぶ大量の下血が起つてショック状態になつた。精力 的な対策の下に $1 〜 2$ 日経過をみたが，止血傾向なく， 直晹鏡検査にて出血源不明なままガーゼタンポンを行

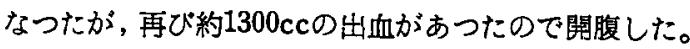
おそらく直腸出血と考えられたが，それより上方の出血 も否定出来ない為，S字結腸に人工肛門，さらに盲腸瘦 
を設置した。しかし翌日再び約 $1300 \mathrm{cc} の$ 出血があり，直 腸出血であるととが確認され再開腹を行ない直腸切開， 大量凝血を除去、出血源を探したが明らかに出来ず、余 儀なく、直腸内につよくガーゼタンポンを入れて䋖合し た。その後 7 ～8 日出血は殆んどなくなり全身状態は改 善したが、ガーゼタンポンが次第に肛門から排されると 又, 約 $1800 \mathrm{cc}$ の出血があつたので直腸切断術を決行し た。乙の切除直腸標本の肉眼的所見では出血部位は不明 であつた。病理検査によつて，はじめて直腸粘膜下組織
の著明な静脈湭形成及び小血管のうつ血状態が認めら れ、これが大量出血の原因であると考觉られた。しかし 患者は大量出血, 大量輸血. 3 回にわたる大手術等の悪 条件が重なつたため。痔核手術後,約 1 ケ月で肝腎障害 を来たし，尿毒症，尿毒症性肺炎を起して術後40日で死 亡した。との文献的にもきわめて桸な症例の経過，とつ た対策等を反省し, 肛門手術前後好置を考察し病理組織 学的所見も加元て報告する。

\section{第 3 日 第 I 全場午前の部}

\section{座長 和 田 寿 郎 教授}

\section{I -68 開心術 200 例の検討}

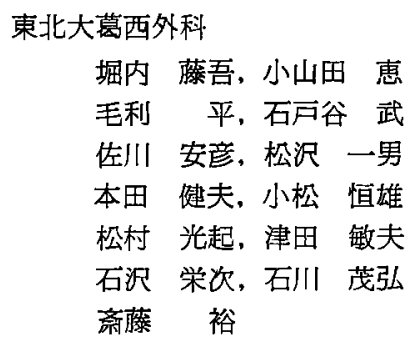

心手術 470 例中, 開心直視手術は 202 例である。うち $25^{\circ} \mathrm{C}$ 前後の表面冷却低体温法を用いたもの112例，人工 心肺によるもの90例である

心房中隔欠損：二次中隔欠損は低温46例（1 例死亡） 人工心肺10(2)。一次中隔欠損は低温 4(1).人工心肺 2 (1) A S D の大部分は低温で手衍しており成績も良好である が、肺高血圧を伴うものは人工心肺の適応としている。 特殊な合併奇型として, 上大静脈へ右肺静眽の異常還流 しているもの 2 例低温で成功。全肺静肺還流異常は 4 例 で全例失敗。

心室中隔欠椇：低温49(10)，人工心肺56(6)。肺動脈収縮 期圧 $80 \mathrm{~mm} \mathrm{Hg}$. 以上のもの 7 (死亡率43\%)，60〜79 $\mathrm{mm} \mathrm{Hg}$ $7(43 \%) ， 40 \sim 59 \mathrm{~mm} \mathrm{Hg} .15(20 \%)$ V V D は概权人 工心肺を用いているが，3才未满の乳幼児は人工心肺が 使えないので低温を用いている。肺高血圧を伴はないも のは成續極めて良好で，伴うものは不良である。肺高血厌 を伴うものは最近著るしく良好となつたが，手術手技の 改良点は，右心機能保全の為右室を横切開するととと。 欠損部にパツチを繾着する時に連続繸合を用いる事であ る。合併奇形として，+P D Aは 5 例で胸骨正中切開で 入り同時手術を行う。球中隔欠損 2 例, バルザルバ洞動 眽鹰破裂 2 例, 左心室一右心房交通症 1 例にいゔれも人 工心肺で成功した。

肺動脈弁狭窄：低温10(2)，人工心肺 $4(0)$ 。28～90
Cの低温でよく経肺動脈幹切開で 充分手術出来る。 $\mathrm{Br}$ ock の弁膜刀による非直視手術でも良い症例があり,特 亿乳児例飞有利と思う。円錐部狭窄は人工心肺の方がよ い。合併奇形は＋A S D 3 例, +修正位大血管転位 1 例 に成功した。

フアロ一氏四徵：人工心肺14(7)。本症は成績不良のた め未だ積極的には根治手術をすすめられない。

人工心肺と低温の適応については, 将来人工心肺は比 較的年長者の複雑な重症例の根治手術に，低温は乳幼児 の開心術にその長所を発揮して適応を拡げてゆくと思わ れる。

\section{座長発言}

札医大胸部外科 和田 寿郎

乳幼児注する人工心肺を用いる根治手術の適応は慎 重である可きものと思う。絶対的適応の評価が要求され るものと思う。

\section{I一69 心マツサージの経験と反省 札幌北農病院外科 前田 晃 北大三上外科西村 昭男, 手戸 一郎 浜田稔 \\ 天使病院外科藤田平治郎}

最近我々の経験した心マッサージ症例中，示陖に富む 5 例を秎介し，で参考䎲供し度い。

第1例 35才，男子，右結核性澧胸兼気管教に対し手 術中突然血圧湘定, 眽膊触知不能となつた。左側卧位よ り仰卧位に体位変換しつつ左胸部に皮切を加えたが、左 肺，左心室をも損傷した。檤合しつつマツサージ行い 数回後膊動再開したが、漸次衰兄，遂に再び停止した。

第 2 例 67才, 男, 食道癌, 左開胸により腫演剔出後 胸骨下を挙上した空腸と頸部食道吻合の為, 側卧位より 仰卧位とした際 Cardiac anestに気付く。開胸、マツ サージにより心膊動再開したが，呼吸麻焷、意識恢復せ 